\title{
INTERNATIONAL JOINT VENTURE CORPORATIONS: DRAFTING OF CONTROL ARRANGEMENTS
}

A merican businesses which desire to internationalize their activi-
ties may conduct their operations abroad through any one of a
diversity of organizational forms. Some businesses have chosen to
open branch offices or organize subsidiaries in foreign countries.
Others have chosen to buy an interest in foreign corporations or to
enter licensing or marketing agreements with foreign enterprises.
One of the most popular and satisfactory choices, however, has been
to organize an international joint venture corporation."
A joint venture corporation is formed when two or more corpora-
tions desiring to be "partners" in some activity organize and hold
the shares of a new corporation. The resulting joint venture corpo-

\footnotetext{
${ }^{2}$ See generally, Friedmann \& Kalmanoff, Joint International Business Ventures (1961) [hereinafter cited as FriedmanN \& KaLManoff].

The reasons American businesses choose to enter joint ventures include: (l) the desire to spread the risk in rather speculative projects or in projects in unstable arcas, (2) the need to raise large sums of capital or credit, (3) the need for the skills or marketing experience possessed by other businesses, (4) the necessity or political advisability of having local interests associated with foreign investment, and (5) a requirement of local governments that they or their public corporations have an interest in any business established by foreign investors. See Blough, Joint International Business. Ventures in Less Developed Countries, in 2 INST. Pruv. InvestMent Adroad 513 (1960); Gutler, Joint Ventures with Foreign Business Associates, Investors and Governments, in 1 lNst. Priv. INvestment Abroad 261, 262.64 (1959); FriedaiAnN \& KALMANOFF 3-5.

The following more theoretical explanations have been given for the increased popularity of joint ventures: (1) the magnitude and integral complexity of today's major commercial projects, (2) the advent of governments as buyers and sellers in the economic field, and (3) the growing habit of cooperation in a society that is outgrowing the crude competition and laissez-faire concepts. BoultoN, Business CoNSORTIA (1961) [hereinafter cited as Boulton].

Whether or not the joint venture is incorporated depends upon the same basic factors which determine whether or not a domestic business incorporates, i.e., tax considerations, anti-trust laws, need for limited liability, formalities and cost of organizing and conducting a business in the corporate form, need for outside financing, the local law as to the corporate form and its moldability, etc. See FriedsanN \& Kalmanoff 212-19; Friedmann \& Pugh, Legal Aspects of Foreign Investment 734.83 (1959) [hereinafter cited as Friedmann \& Pugh]; Landau, check list, in 2 Doing BusiNESS ABROAD 620, 622-38 (1962).

2 Defining the term "joint venture" presents many problems. Unincorporated joint ventures are often difficult to distinguish from partnerships. See Taubman, THE Joint Venture and Tax Cuassificamon 1-136 (1957). The definition used for this paper is that of Friedmann and Kalmanoff: "In the widest sense, the 'joint venture' comprises any form of [husiness] association which implies collaboration for more than a very transitory period." FruEdManN \& Kalmanoff 6. The prevailing British term for "joint venture" seems to be "business consortium." A business consortium is an
} 
ration can be considered "international"3 when its organizers and shareholders are of differing nationality or when the nationality of the joint venture corporation differs from that of its shareholders."

"organisation which is brought into being to enable two or more companies to operate as a single entity for a prescribed and limited purpose." (All italicized in original.) BouLron 5.6.

Technically speaking, any "joint venture" which is incorporated could be called a "joint venture corporation." Its shareholders and organizers could be individuals and partnerships as well as corporations. However, the descriptive definition given in the text seems the most accurate description of the large majority of domestic and international joint venture corporations. The descriptive definition is suggested by Professor Hale's statement that a joint venture corporation is "a corporation whose stock is owned by other corporations and which engages in a business different from that of its parents (even though the difference be only that it sells its products in a foreign territory)." Hale, Joint Ventures: Collaborative Subsidiarics and the Antitrust Laws, 42 VA. L. Rev. 927 (1956). See also, 1 O'Neal, Close Corporations: Law \& PRActice $\$ 1.06$ (1958) [hereinafter cited as O'NEAL].

a When an international joint venture corporation is organized under laws other than those of the United States, the word "corporation" is meant to refer to the forms of business organization under the foreign law which are comparable to American corporations-for example in France, the societte anonyme and the societe à responsabilite limitee.

For a discussion of the various forms of business organization abroad, see FrIEDMANN \& Pugh 754-59. See also, Drachsler, Business Organization and Operation in Sweden, in 1 Dolng Business Abroad 155 (1962); Gower, The English Private Company, 18 LAW \& CoNTEMP. Proв. 535 (1953); Haight, Form of Business Organization: United Kingdom-Australia-Canada-India, in 1 DoINc Busıness ABRoAD 171 (1962); Houwink, The American Close Corporation and its Dutch Equivalent, 14 Bus. LAw. 250 (1958); Littauer, Business Organization in Switzerland and Belgium, in 1 DoING Business Arroad 163 (1962); MrFadyean, The American Close Corporation and its British Equivalent, 14 Bus. LAw. 215 (1958); Nattier, Local Business Organization and Operation, in DoING BusIness ABROAD 72 (1962); Pavia, Business Organization in Italy, in 1 DoING Business ABroad 150 (1962); Steefel, Selection of Form of Business Organization and Problems of Control and Operation in the Federal Republic of Germany, in 1 DoInc Business Abroad 219 (1962); Strobl, Principles of the German Law of Partnerships and Corporations, in 1 DoInc BusINess AbroAd 114 (1962); Torem, Business Organization and Operation in France, in 1 Dolvg Business ABROAD 138 (1962); Treillard, The Close Corporation in French and Continental Law, 18 LAW \& CoNTFMP. Pros. 546 (1953); Yamaoka, Business Organization in Japan, in 1 DolNg Business ABROAD 191 (1962).

4It could be argned that a joint venture corporation should be considered "international" if all or most of its activities are abroad even though all of the shareholders are "nationals" of the country of incorporation. ARAMCO, Arabian American Oil Company, is for example one of the most important joint venture corporations which operates on an international basis. It is, however, excluded from the above definition because it is organized in Delaware and all of its sharcholders are American corporations. It seems best to exclude ARAMCO from the "international" category for the purposes of this paper since its control problems would seem to be almost exclusively the same as if it were simply a domestic close corporation with no international connections.

The criteria used to determine the "nationality" or "national origin" of a corporation vary from jurisdiction to jurisdiction and according to the purpose for which the designation is sought. The factors which are frequently considered influential or determinative include: (1) the place of incorporation, (2) the location of the head office (siège social), (3) the location of the principal operations of business of the 
It is these international joint venture corporations (or IJVG's as they will be called) that this comment will consider.

A key concept in the legal analysis of any aspect of joint venture corporations is the realization that whether international or domestic they are close corporations. In fact,

The shareholders in a joint venture corporation are few in number; they normally do not plan to dispose of any of their shares to outsiders; they consider themselves joint venturers (in other words, "partners" engaged in an undertaking of limited scope), just as shareholders in a close corporation often think of themselves as partners; and the participants and their attorneys, in organizing a joint venture corporation, often want to deviate from the traditional pattern of corporation management.

In view of these characteristics and the underlying desires of the participants which they reflect, the lawyer who plans a joint venture corporation must mold the corporate form through the use of various control devices so as to create an organizational structure which will effectuate the desires of his clients. Primary among such devices are (1) classification of stock and classification of directors, (2) high vote and high quorum requirements, (3) restrictions upon the transferability of shares, (4) informal action clauses, (5) arbitration clauses, and (6) shareholders' agreements and voting trusts. ${ }^{6}$ With only a few modifications to reflect differing laws, the same basic devices seem to have enabled the attorney to do his job of molding the corporate form whether organizing a domestic close corporation or an IJVC.

\section{Classification of Stock and Classification of Drrectors}

The type of control arrangement which an attorney will wish to employ is, of course, determined by the problem presented and

company, (4) the nationality of the majority or controlling shareholders, and (5) the nationality of the management of the company. See Kronstein, The Nationality of International Enterprises, 52 CoLUM. L. REv. 983 (1952); McNair, The National Char. acter and Status of Corporations, 4 BRIT. YB. INT'L L. 44 (1923-24). See also, Baade, Diplomatic and Treaty Protection of Nationals Who Are Shareholders in Legal Entities Organized or Created Under the Law of a Foreign State Against Actions of the Creator State with Respect to Such Entities (1955) (unpublished thesis in Duke University School of Law Library).

- 1 O'Neal 10.

- A more controversial control device not listed above is the management contract. It does not basically involve the molding of corporate forms through drafting and is therefore outside the scope of this comment. For discussions of the use of management contracts, see Cutler, Joint Ventures with Foreign Business Associates, Investors and Governments, I INST. Priv. Investment Abroad 261, 265-70 (1958); Friedmanin \& KALMANOFF ch. VI. 
the solutions allowed by the law under which the corporation is being formed. Classification of stock and classification of directors are particularly suitable when it is desired to depart from the general principle that corporate control is proportionate to capital contributions or ownership of shares. ${ }^{7}$

Such a departure was desired by the organizers of FRIA, an IJVC formed to extract bauxite in French Guinea. ${ }^{8}$ In organizing FRIA, it was decided that the equity contribution of and the percentage of shares held by the organizers should be in proportion to the part of the new corporation's production to be purchased by each of the organizers. This meant that the two French companies (Pechiney and Ugine) would jointly own only $26.5 \%$ of the corporation's shares. Local political conditions, however, made it necessary that Pechiney and Ugine control FRIA even though another shareholder, Olin Mathieson, held nearly one-half of the shares.

FRIA's control problem was met by setting up a class of stock for each of the organizers and by subdividing each class into two series. Each share in the first series was assigned one vote and each share in the second series was assigned ten votes. ${ }^{9}$ The number of shares assigned to each series was fixed so as to give voting control to Ugine and Pechiney. Enough ten-vote shares were assigned to Olin Matheison so that when combined with high vote requirements, Olin Matheison had a veto over certain corporate actions and thus could protect its large capital investment.

Although local law precluded ordinary classification of directors

\footnotetext{
T See 1 O'NeAL $\$ \$ 3.11-.39$.

'FRIA, Compagnie Internationale pour la Production de l'Alumine, was incorporated in 1957 under the laws of French Guinea (now the independent Republic of Guinea). The following corporations were the organizers and shareholders: Olin Mathieson Chemical Corporation (American), Pechiney (French), Ugine (French), The British Aluminum Co., Ltd. (British), Aluminium Industrie Aktiengesellschaft (Swiss) and Vereingte Aluminium-Werke Aktiengesellschaft (German).

See Adkins, Gilpatric \& Abraham, Corporate Joint Ventures in Operation, 14 Bus. LAw. 285, 300.08 (1959) (all information in this paper concerning FRIA is taken from the Adkins article).

- French law (then generally in effect in French Guinea) ordinarily prohibits different voting rights for shares representing the same proportion of capital. FrIEDMANN \& PUGH 226. A new French decree applying to Overseas Territories permitted use of plural voting rights in FRIA. Adkins, Gilpatric \& Abraham, supra note 8, at 303.04.

The use of multivote shares is generally not possible for drafters of charter clauses for American close corporations since many states provide that each share must have one vote. 1 O'NEAL $\$ \$ 3.16$ \& 3.18. Some American states even forbid non-voting stock. Id. at $\$ \S 3.18 \& 3.21$
} 
by providing that all directors must be elected by all of the shareholders regardless of class, a modified but just as effective type of of director classification was achieved by providing that a certain number of directors must be elected from nominees chosen by the holder of the classes of stock which were assigned to Ugine and Pechiney. This nomination method of classifying directors seems popular in several European countries but is not generally used in the United States. ${ }^{10}$ The way that a nomination type clause is drafted can be seen from the following charter clause taken from an IJVG organized in the Netherlands Antilles:

The authorized capital of the company is five million Netherlands Antilles florins, divided into 5,000 common shares of 1,000 florins par value each, numbered from 1 to 5,000 exclusively of which 2,500 shares numbered from I to 2,500 inclusive have been subscribed for.

The appointment of three (3) members of the Board of Directors shall be made from a select list of at least two candidates for each vacancy; said list shall be drawn up by the holder(s) of the shares numbered 1 to 1250 inclusive. ... The appointment of the remaining three (3) members of the Board of Directors shall be made from a select list of at least two candidates for each vacancy; said list shall be drawn up by the holder(s) of the shares numbered 1,250 to 2,500 inclusive. . . .11

The wording of a clause using the more direct classification of directors that is often used in domestic close corporations can be seen in the charter provisions of French IJVC:

The company's capital is fixed at - NF divided into - shares in the amount of - NF distributed as follows:

- shares in series A, numbered...

- shares in series $B$, numbered ...

The company is managed by a Board of Directors composed of eight members, two of whom are elected by the shareholders owning at least

${ }^{20}$ There seems to be some use of the nomination method in the United States for charitable corporations. See, e.g., By-laws of Highland Hospital, Inc., Asheville, North Carolina, art. I, $\S 1$ : "The Board of Directors of this corporation shall be composed of the members of the corporation and shall consist of eleven (I1) directors; provided, however, no person shall be elected a (member) director unless he or she has been nominated as such by the Executive Commmittee of Duke University, Durham, North Carolina. Each director shall hold office for a term of one (I) year and until his successor shall be elected and quailfied."

11 This and other quotations from corporation documents were obtained in confidence and the sources and names of the corporations cannot be divulged.

It should be noted that one of the problems involved in doing research concerning IJVC's is the difficulty of obtaining materials. This difficulty results from the highly developed sense of business secrecy that prevails abroad. 
four shares of the " $A$ " series and six elected by the shareholders owning at least four shares of the " $B$ " series. 12

Classification of shares and classification of directors is therefore the same effective device for allocating control in an IJVC as it is in a domestic close corporation. Since, however, the classification device must be adapted to local law, the attorney may find it necessary or desirable to use multivote shares, the nomination method of director classification, or some other variation. ${ }^{13}$

\section{High Vote Requirements and Veto Provisions}

The shareholders of a close corporation generally think of themselves as partners rather than as fellow shareholders. ${ }^{14}$ They therefore frequently desire to depart from the principle that on most corporate matters the vote of a majority of the shares is controlling. In some close corporations-especially the joint venture variety-the shareholders will even desire that all decisions be unanimous. Attorneys for close corporations-international and domestic-effectuate these desires by drafting charter and by-law provisions requiring unanimity or a high percentage of votes for all or selected corporate acts. ${ }^{15}$ High vote and veto provisions are often strengthened by the addition of high quorum requirements. ${ }^{16}$ The following excerpt shows how a high vote-high quorum, and in effect veto, clause was drafted for the Netherlands Antilles IJVC:

No resolutions may be adopted at any general meeting of shareholders unless a quorum of the holders of at least two-thirds of the outstanding capital stock is present or represented, and all resolutions shall be adopted by at least a majority of two-thirds of the votes cast. ${ }^{17}$

1s See note Il, supra.

${ }^{18}$ The use of founders' shares may also be an effective method of share and director classification which is not available under American law. See Boulron 80 .

It should be remembered that an international joint venture corporation may be organized in the United States, and in such a case the use of classification of shares and directors as well as all corporate control devices will depend upon the laws of the state of incorporation.

For an example of the various provisions of local law that need to be considered, see Schmid, Corporate Control in Switzerland, 6 Ax. J. Comp. L. 27, 27-86 (1957).

1s Hence the name "incorporated partnership." See 1 O'NEAL. 3.

${ }^{15}$ Id. at ch. IV.

${ }^{10}$ Id. at $\$ 4.22$.

${ }^{17}$ See note 11, supra.

Since there were only two shareholders-each of which owned $50 \%$ of the stock, the above clause is in effect a provision requiring unanimity of the shareholders for all corporate actions. The unanimity requirement would, of course, cease if enough additional shares were issued or if enough of the already issued shares were transferred to outsiders. Since the above quoted portion of the clause in effect requires unanimity, 
An interesting use of high vote requirements combined with classification of stock is employed in the articles of incorporation of Icollantas, ${ }^{18}$ an IJVG organized in Colombia. The B.F. Goodrich Corporation contributed only about one-third of the capital for Icollantas, but wanted and acquired a strong voice in the control of the business. The shares of Icollantas are divided into Classes $\mathrm{A}$ and B. Goodrich is assigned all of the shares of Class B-representing about one-third of the total equity. The articles of incorporation provided, however, that a $60 \%$ vote of each of the two classes of stock is required for such important matters as changing of the composition and election procedures of the board of directors, changing the preferential rights of existing shareholders to subscribe to new shares, and dissolution of the corporation. Goodrich has the same veto over important corporate decisions in its Philippine joint venture. ${ }^{10}$ In the latter enterprise, the veto power is given purely through a high vote requirement. Goodrich owns $43 \%$ of the stock but a two-thirds vote is required on all important corporate matters.

High vote and high quorum clauses can be used to give minority shareholders control of, or an equal voice in the control of, the board of directors. The articles of incorporation of the Netherlands Antilles IJVC provides that:

The majority of the whole board shall consitute a quorum in all meetings for the conduct of all business provided that at least two directors appointed from the select list drawn up by the holders of the shares numbered 1 to 1,250 and two directors being appointed from the select list drawn up by the holders of the shares numbered 1,251 to 2,500 are present or represented by alternates. The action of at least two-thirds of the members of the board so present shall constitute the action of the Board of Directors . ... . ${ }^{20}$

the remainder of the clause provides that in the event such a majority or quorum cannot be obtained at a meeting, then a second meeting shall be held. If there is still no quorum or no majority vote, then a third meeting shall be held at which "Valid resolutions may be taken with a majority of the votes cast regardless of the proportion of the capital stock present or represented thereat." This provision does not, of course, provide a means of breaking a deadlock; since the shares were evenly divided, no majority conld ever be obtained so long as both shareholders attended and voted. The only protection offered is that one shareholder cannot paralyze the corporation by his absence. For methods of dealing with deadlock, see 2 O'NEAL, ch. IX.

${ }^{18}$ See Friedmann \& Kalmanoff $157,158$.

${ }^{19}$ Id. at 159 .

${ }^{20}$ See note 10 supra.

For the classification of the corporation's shares, sec p. 520, supra. 
The articles of incorporation of the French IJVC follows the pattern often found in domestic close corporations and provides that only a majority vote of a majority quorum is necessary for ordinary director action, but requires director unanimity for actions relating to dissolution, amendment of the bylaws and referral of matters to the shareholders. ${ }^{21}$

\section{Restrictions on the Transferability of Shares}

The shareholders of a close corporation frequently desire to keep "outsiders" from obtaining an interest in the corporation. In the small domestic close corporation the desire may be motivated by the fear of becoming "partners" with strangers or unacceptables. ${ }^{22}$ The motivation in an IJVC would seem to come primarily from the fear that competitors will obtain an interest in the joint venture or that a financially sound joint venturer will be replaced by a less stable or unknown one.

The answer to the problem for both domestic close corporations and IJVC's lies in a departure from the general corporate principle of free transferability of shares and the imposition of some type of restriction on the transfer of the joint venture corporation's shares. ${ }^{23}$ In IJVG's, as well as in domestic close corporations, the first option type of restriction seems to be the most used and the most satisfactory.

The articles of incorporation of the French IJVC contains a first option provision strikingly similar to those recommended for domestic close corporations:

No shareholder may transfer all, or a part of his shares without having offered them to the other shareholders who shall enjoy a preference right to purchase them.

The proposal shall be made to the Board of Directors in a registered letter with acknowledgement of receipt, advising of the number of shares to be transferred, the price, as well as the name, surname, profession and address of the eventual purchaser or purchasers, if any.

\footnotetext{
Dee note 10 supra.

222 O'NEAL $\$ 7.02$.

${ }^{20}$ For a discussion of the use of restrictions on the transferability of shares in an international joint venture corporation, see FriedManN \& KaLMANOFF 223-24. Compare the discussion on restrictions on the transferability of shares of domestic close corporations in 2 O'NeAL ch. VII.

It should be noted that registered rather than bearer shares should be used in cases in which both types are permitted so as to facilitate the use of transfer restrictions, See Friedmann \& Pugh 62-63.
} 
Within the month following receipt of such a letter, the Board shall inform the shareholders of the number and price of the shares to be transferred in a registered circular letter with acknowledgement of receipt sent to all of them, or as an alternative, by having this same information put in a legal advertising paper published in the département of the Head Office.

Shareholders will have fifteen days to advise the Board of Directors in a registered letter with acknowledgement of receipt as to whether they wish to buy the shares put on sale.

Should acceptable offers be made which would amount to a demand in excess of the number of shares for sale; these shall be distributed in proportion to the number of shares held by the shareholders who will have made such purchase proposals and within the limit of their requests.

The Board of Directors is especially entrusted with the settlement of such distribution. If, however, no acceptable offer has been made within the said fifteen days time, the Board will be at liberty to seek a third party purchaser and will have, for that purpose, one month's time starting from the termination of the fifteen day period.

If, upon termination of this new one month's time, the Board has not been able to find any person, whether a shareholder or not, as purchaser, the selling shareholder will be free to dispose of his shares as he sees fit. ${ }^{24}$

\section{INFORMAL DIRECTOR AGTION}

A characteristic desire of the shareholders of a close corporation . is that they and especially their chosen directors be able to act as quickly and informally as partners can. The need for such informal action is especially acute in an IJVG because the head offices of the shareholder-corporations may be in widely separated regions of the world and far distant from the country in which their joint venture is operating. The problem has been somewhat alleviated for domestic close corporations by charter and statutory provisions authorizing the directors to act informally. ${ }^{25} \mathrm{~A}$ charter provision to this effect may also be desirable for an IJVC and the following one is found in the Netherlands Antilles joint venture corporation previously discussed:

The company will be represented in and out of courts and will be bound toward third parties by two directors jointly, provided that one of these directors is one nominated from the select list drawn up by the holders of the shares numbered from 1 to 1,250 and provided that the other is one of those nominated from the selected list drawn up by the holders of the shares numbered 1,251 to $2,500.26$

\footnotetext{
24 See note 11 supra.

${ }^{25}$ See O'NeAL $\$ \$ 8.03,3.62$.

${ }^{20}$ See note 11 supra.
} 


\section{arbitration Clauses}

In the past few years there has been a remarkable growth in the use of arbitration to settle disputes among the shareholders of close corporations. Arbitration clauses were at first of doubtful validity in many American jurisdictions, but have now been expressly allowed by many statutes and have become a common charter clause in form books. ${ }^{2 \pi}$ The use of arbitration seems especially advisable for IJVC's. The complexities which arise from the involvement of corporations and individuals of varying nationalitiesrepresentative of numerous legal and economic systems-makes it impossible for the attorney to foresee all problems which will arise.

The mechanics of drafting arbitration clauses for IJVC's and domestic close corporations does not differ appreciably. The drafter may use one of two types of clauses. One type of arbitration clause refers the dispute to an arbitral organization which has set rules and a set procedure. ${ }^{28}$ An American attorney may even follow the formbook suggestion that any dispute be submitted for arbitration to the American Arbitration Association. ${ }^{29}$ That association is wellequipped to handle disputes arising out of international transactions, and its rules provide for the use of foreign arbitrators when they are requested by one of the parties. ${ }^{30}$ If the clients do not wish to use an American association, nearly every major trading country in the world has a well-respected arbitration association-there is even one for the Soviet bloc. ${ }^{31}$

Should the organizers of an international joint venture corporation not wish their potential disptues to be submitted to an association, the drafter may, as is frequently done for domestic close corporations, provide that each side to the arbitration shall choose one person and that the two arbitrators so selected shall choose a third. Or a well-respected person of neutral nationality may be designated

The above quoted clause goes beyond authorizing informal action to authorize less than a majority of directors to bind the corporation. American statutes and practice generally allow informal action only when all or a majority of the directors act. The authorization of action by fewer than a majority seems peculiarly appropriate to a corporation which has more directors than shareholders.

or See 2 O'NeAL $\$ \$ 9.08-.25$.

18 See Domke, International Arbitration of Commercial Disputes, 2 Insr. Prav. INVESTMENT ABROAD 131 (1960).

See 2 O'NeAL $\$ 9.23$.

30 Commercial Arbitration Rules of the American Arbitramon Association $\S 15$.

s2 Domke, supra note 28 , at 149 . 
to appoint all of the arbitrators or the third arbitrator..$^{82}$ An example of this second type of arbitration clause is found in the shareholders' agreement of an IJVC incorporated in Italy:

All controversies between shareholders in relation to the interpretation and application of this agreement, or any modification or extension thereof, shall be resolved by a college of three amicable arbitrators, from whose decision there shall be no appeal. Such arbitrators will be nominated one by each shareholder and the third by mutual agreement or, failing that, by the President of the Geneva Tribunal. Such arbitrators may act without procedural formalities, and shall have faculties and powers to investigate and decide..$^{33}$

\section{Shareholders' Agreements and Voting Trusts}

One of the most effective ways of arranging for the control and direction of a domestic close corporation is by a shareholders' agreement. The purpose of these agreements is to set forth in writing the general business agreement of the parties. ${ }^{34}$ It generally encompasses such matters as the persons to be selected as directors and officers, the business policies to be followed by the corporation, the settlement of disputes, and any restrictions which are to be placed upon the transferability of shares.

A shareholders' agreement (or joint venturers' agreement as it is sometimes called) is a valuable and often indispensable tool for the attorney of an IJVG. ${ }^{35}$ The pattern to be followed in such ań agree-

\footnotetext{
${ }^{32}$ For a discussion of some disadvantages of this type of arbitration as opposed to submission to an arbitration association, see 2 O'NeAL $\$ 9.22$.

${ }^{33}$ See note 11 supra.

A limited use of arbitration was made in the French international joint venture corporation discussed above in that the price for the purchase of shares under the first option provisions is to be set by arbitration.

84 "It is the inevitable experience of everyone who takes in hand the drafting of a commercial agreement that the act of setting down in black and white the rights and obligations of the parties is the best means of throwing light on the uncertainties and ambiguities, and of compelling the parties to reach precision in their thinking." BoutTON 52.

Professor Boulton suggests for jont ventures (business consortia) a "formation agreement." BouLton chs. V-VI. This formation agreement is in essence a combination of a shareholders' agreement and the preincorporation agreements often used in the organization of domestic close corporations. Indeed it scems that pre-incorporation agreements are another close corporation control device that may be useful to the organizer of an international joint venture corporation. For a discussion of preincorporation agreements, sce 1 O'NEAL $\$ 2.23$.

${ }^{85}$ In addition to the agreements as to control which are generally found in the shareholders' agreements of domestic close corporations, there are a number of other matters arising in international joint venture corporations which could be treated in the shareholders' agreement, but which seem to be traditionally treated in scparate documents. Examples of such matters are production and marketing agreements and financing arrangements.
} 
ment is basically the same as for a domestic close corporation. ${ }^{36}$ For example, the shareholders' agreement for an Italian IJVG contains the following: (I) A first option provision as to the transferability of shares; ${ }^{37}$ (2) a provision that the directors of the corporation "shall be nominated and elected by the shareholders in the exact or aproximate ratio of their respective equity share ownerships"; 38 (3) a provision that unanimous agreement of the shareholders is required for such matters as liquidation, approval of contracts between the corporation and its shareholders, and the exercise by the corporation of first option rights; (4) an arbitration clause; (5) a provision that Italian law is to govern the agreement; (6) and a provision stating the period of time during which the agreement is to be effective.

One of the primary considerations in the use of a shareholders' agreement is the problem of its validity and enforceability. There is no general consensus on this question among the American jurisdictions and the practice abroad is also quite varied, running from clear validity in Italy to clear invalidity in France. ${ }^{39}$ It seems, however, that there is at least some tendency among American companies to enter into shareholders' agreements even if they are not valid and enforceable on the theory that the business bargain needs to be set out in writing for purposes of clarification, and that legal enforceability is not essential since parties who can't trust each other shouldn't be in business together. ${ }^{40}$

The voting trust has proved an effective control device for close corporations in many American jurisdictions. Their very limited use on the international scene is perhaps attributable to the nonexistence of trusts in most noncommon law jurisdictions, and to their cumbursomeness as compared with shareholders' agreements. A limited use of a voting trust was, however, made in the Volta River project in which Kaiser Aluminum and Reynolds Metals formed

\footnotetext{
${ }^{85}$ See 1 O'NeaL, ch. V.

${ }^{97}$ The transfer of shares by a shareholder to one of its subsidiaries is allowed without compliance with the first-option provision.

${ }^{\text {si }}$ See note 11, supra.

${ }^{30}$ See Friedmann \& Pugh 228. At least in France sharcholders agreements are valueless since it is illegal to have a contract involving a promise to vote in a certain way. For German and Swiss law, see Schmid, Corporate Control in Switzerland, 6 AM. J. CoMp. L. 27 (1957).

"O "There must be a constant recognition that the problems of one member can seldom be fully understood by others and there must accordingly be a consequent determination on the part of all members to trust the others. Unless such a trust can exist it is better for the consortium not to be formed at all." Boulrow 36.
} 
VALCO, an IJVC organized under the laws of the Republic of Ghana.41 The shares of VALCO were placed in a voting trust, but it seems to have been used for the protection of the Government of Ghana and the corporation's creditors rather than as an intershareholder control device. ${ }^{42}$

In spite of their limited use, voting trusts should at least be considered by an attorney organizing an IJVC, especially if it is being organized in a jurisdiction in which shareholders' agreements are unenforceable.

\section{Governments as Shareholder-Partners}

The fact that it is often necessary or desirable to include a government or a wholly government-owned corporation as one of the participants in an international business, is often the reason for choosing the joint venture corporation as the organizational form. ${ }^{43}$ The presence of such a shareholder creates a control problem since,

1 VALCO, perhaps the most spectacular of all international joint venture corporations, was formed in 1959 by Kaiser Aluminum \& Chemical Corporation and the Reynolds Metal Company. The purpose of the venture is to develop and exploit the bauxite-rich Volta River region of Ghana. The project was financed through the help of the U.S. Agency for International Development, the Export-Import Bank of Washington, the Export Credits Guarantee Department of the Board of Trade of the British Government, and the International Bank for Reconstruction and Development. The cost of the smelter alone was estimated at $\$ 120,000,000$. The equity contribution of Kaiser and Reynolds (about $\$ 32,000,000$ ) was guaranteed by the U.S. Intcrnational Co-operation Administration. Another interesting feature is a buy-out agreement in a third party. AID has agreed, in certain specified events which include war and nationalization, upon the request of the shareholders to purchase their shares The Volta River Project: Statement by the Government of Ghana (1962); Nurick et al., A Case Study: The Volta Aluminum Company Project, in Wordd Community association, Legal. Problems of International. Financing (to be published).

12 "The Voting Trust Arrangements . . . are designed primarily to ensure to the interested parties .... that the smelter will be completed. These arrangements provide that all of the shares of Valco will be deposited with a trustee which is obligated, under certain circumstances, including undue delay in building the smelter, to remove the entire management of Valco and replace it temporarily with a firm of engincers to be selected within three years after the signing of the agreement. The Voting Trustee under the arrangement is Morgan Guaranty Trust Company of New York ...." The Volta River Project; Statement by tile Government of Ghana 11-12 (1962).

There is also a "Valco Current Accounts Trust." "This trust is designed, among other things, to assure that the obligations of Valco under the Power Contract will be treated on a pari passu basis with those of the Export-Import Bank, and also provides for the enforcement by the trustee of the payment of certain obligations which the shareholders of Valco owe to Valco." Id. at 12.

${ }^{18}$ In fact, especially in some Latin American countries, Amcrican businesses may have no option. They must invest in joint ventures with local or government-owned business-or not at all. Sce note 1, supra; Columbia Society of INTERnational LAw, Legal. Problems of Trade and Investment in Latin America (to be published).

See generally, Cutler, Joint Ventures with Foreign Business Associates, Investors and Governments, in 1 INST. Priv. INVEst. Abroad 261, 279-84 (1959). 
according to the doctrine of sovereign immunity, the contracts made by a sovereign are morally binding on it.44 Sovereigns can therefore generally be held liable for breaches of charter clauses and shareholders' agreements only if they consent to be held and voluntarily pay damages or obey specific performance orders. The situation has been alleviated somewhat as to suits brought against one sovereign in another sovereign's courts by the growing acceptance of the restrictive doctrine of sovereign immunity. ${ }^{45}$ It has also been the practice in international business circles to obtain a waiver of immunity from the sovereign. However, a recent American case has cast doubt on the value of such waivers by recognizing the right of a soverign to repudiate even a voluntary and unconditional waiver. ${ }^{46}$

There seems to be no safe solution to the control problem presented by governmental shareholders. The attorney can only help his client weigh the potential business advantages of having governments as shareholders versus the uncertainty that may come from the impotence of control arrangements to bind sovereigns. ${ }^{47}$

"This problem is closely analogous to the presence of a minor as a shareholder in a domestic close corporation. A minor can sign a shareholders' agreement and if he does not affirm it upon coming of age or if he violates it before coming of age, it will be unenforceable as to him. So also, a government who is a shareholder can always break any agreement with the corporation or with other shareholders because as the United States Supreme Court has said, "The contracts between a nation and individuals are only binding on the conscience of the sovereign, and have no pretentions to a compulsive force. They confer no right of action independent of the sovereign will." Principality of Monaco v. Mississippi, 292 U.S. 313, 325 (1934).

\&I The U.S. Department of State in announcing the U.S. acceptance of the restrictive theory stated: "According to the new or restrictive theory of sovereign immunity, the immunity of the sovereign is recognized with regard to sovereign or public acts (jure imperii) of a state, but not with respect to private acts (jure gestionis)." The announcement went on to state: "The Department feels that the widespread and increasing practice on the part of governments of engaging in commercial activities makes necessary a practice which will enable persons doing business with them to have their rights determined in the courts." Letter of the Acting Legal Adviser of the State Department, Jack B. Tate, to the U.S. Attorney General Concerning Sovereign Immunity of Foreign Governments, 26 DEP'T STATE Bull. 984 (1952).

The doctrine is of only limited help, however, since it does not allow execution against even the commercial property of a sovereign, nor does it affect the suability of a sovereign in its own courts.

${ }^{10}$ Rich v. Naviera Vacuba, 197 F. Supp. 710 (E.D. Va.), aff'd, 295 F.2d 24 (4th Cir. 1961). See Note, 1962 Duke L.J. 582.

47 While a sovereign is not legally bound on its contracts, it is nevertheless morally bound. Indeed, the sovereign may be quite reluctant to break this moral obligation and thus alienate the international business and finance circles.

It seems that a voting trust (see p. 527 supra) might be effectively used when a government or a government-owned corporation is a shareholder. The Government could, of course, eventually get its way by expropriating the joint venture's property inside its territory, but if the government were unwilling to go this far, a voting 


\section{Conclusions}

The materials available on control arrangements for IJVC's are sparse. With the increasing use of IJVC's, more research and pooling of knowledge is definitely needed. There should be intensive studies to see exactly what problems and pitfalls the drafter should seek to avoid. There needs to be a comprehensive planning-and-draftingoriented work which would assimilate the applicable portions of studies concerning domestic close corporations to the needs and characteristics of IJVC's. ${ }^{48}$

The materials which are presently available do, however, clearly support the following three theses: (I) IJVC's are in essence close corporations and therefore have many of the same control problems as do domestic close corporations. (2) The control problems of an IJVC can be and are best solved by the same devices which are used in domestic close corporations-namely, classification of stock and classification of directors, high vote and high quorum requirements, restrictions on the transferability of shares, informal action clauses, arbitration clauses, and shareholders' agreements. (3) The same techniques $^{49}$ which the American attorney has learned to use in drafting these various control devices to fit the needs of the purely domestic close corporation are also applicable when he is confronted with the opportunity of organizing and advising an IJVC.

trust would offer some protection to the private shareholders from a change of govern. ment policy toward the control of the joint venture corporation.

${ }^{18}$ This paper has attempted to ferret out some of the modifications which necd to be made in traditional control devices so as to better fulfill the needs of international joint venture corporations. There seem to be whole areas that are untouched. For example, do international joint venture corporations share the domestic close corporation's vulnerability to "squeeze outs?" For a discussion of domestic "squeeze out" problems, see O'NEAL \& DeRwIN, EXPULSION OR OPPREsSION OF Business Associates: "SQUeEze-OUts" IN SMALl ENTERPRISEs (1961); O'Neal, Minority Owners Can Avoid Squeeze-Outs, 41 HARv. Bus. REv. 150 (March/April 1963).

to Attorneys for both domestic and international close corporations must be aware of all branches of the law which may affect their close corporations. One of the most important legal fields for international joint venture corporations and one that may be determinative of many drafting needs is antitrust law. See, for example, United States v. Pan American World Airways, Inc., 193 F. Supp. 18 (S.D.N.Y. 1961); United States v. Minnesota Mining \& Mfg. Co., 92 F. Supp. 947 (D. Mass. 1950), 96 F. Supp. 356 (D. Mass. 1951); W. R. Grace \& Co. v. Civil Aeronautics Board, 154 F.2d 271 (2d Cir. 1946), dismissed, 332 U.S. 827 (1947); Friedmann, Antitrust Law and Joint International Business Ventures in Economically Underdeveloped Countries, 60 CoLum. L. Rev. 780 (1960); FRIEDMaNN \& KalmanofF 245.57; Joint Oil Producing Ventures in the Middle East: Their Status under United States Anti-Trust Laws: A Submittal by Standard Oil Company (New Jersey) to the Attorney General's National Committee to Study the Anti-Trust Laws (1953); Kelleher, The National "Antitrust" Laws of Europe, in Dorng Business ABROAD 286 (1962); Weisier, Antitrust Aspects of the Joint Venture in the European Economic Community, 111 U. PA. L. REv. 421 (1963). 